\title{
PEMANFAATAN METODE TES CEPAT MOLEKULER (XPERT MTB/RIF) DI KABUPATEN SORONG TAHUN 2014-2018
}

\section{Utilization of Molecular Rapid Test Method (XPERT MTB/RIF) in Sorong District Year 2014-2018}

\author{
Kristina, Dian Perwitasari, Dina Bisara Lolong \\ Puslitbang Upaya Kesehatan Masyarakat, Badan Litbang Kesehatan \\ Naskah masuk: 16 Juni 2020 Perbaikan: 14 Agustus 2020 Layak terbit: 25 Agustus 2020 \\ https://doi.org/10.22435/hsr.v23i3.3321
}

\begin{abstract}
ABSTRAK
Penyakit tuberculosis (TBC) merupakan masalah kesehatan di dunia, termasuk di Indonesia. Menurut WHO (World Health Organization) populasi orang dewasa lebih banyak terpapar TBC. Penemuan kasus TBC sedini penting dalam upaya pencegahan penularan penyakit. Keterlambatan diagnosis kasus TBC dan ketidakteraturan pengobatan memperbesar peluang transmisi di masyarakat. Pemeriksaan tes cepat molekuler (TCM) dapat mendeteksi lebih akurat kasus konfirmasi kultur TBC dibanding dengan pemeriksaan mikroskopik. RSUD Kabupaten Sorong telah menerapkan penggunaan metode diagnosa TBC dengan tes cepat molekuler sejak 2014 hingga saat ini. Tujuan penulisan artikel untuk mengetahui gambaran pemanfaatan TCM di Kabupaten Sorong dari Tahun 2014-2018. Disain penelitian potong lintang. Populasi adalah suspek TBC yang diperiksa TCM di RSUD Kabupaten sedangkan sampel adalah semua suspek TBC yang dirujuk ke RSUD Kab Sorong untuk pemeriksaan TCM periode 2014-Juli 2018. Data sekunder yang dikumpulkan: identitas pasien, asal rujukan, jenis specimen yang diperiksa, tujuan pemeriksaan, status pengobatan pasien, dan hasil pemeriksaan TCM. Pemeriksaan TCM sebagian besar laki-laki (54,5\%), umur 15-54 tahun (71,3\%), asal rujukan dari internal faskes $(38,7 \%)$ dan Puskesmas (37,8\%). Pemeriksaan TCM sebagian besar pasien TBC kasus pengobatan ulang yaitu $88-90 \%$ tahun 2014-2016 dan 53-66\% tahun 2017-2018. Setiap tahun pemeriksaan TBC resisten obat (RO) berkisar (47-87\%). Dari seluruh total pemeriksaan TCM diperoleh hasil 25,7\% rifampisin sensitive, dan $5 \%$ rifampisin resisten. Kesimpulan: Pemeriksaan TCM sebagian besar laki-laki, umur 15-54 tahun, dan asal rujukan dari internal fasyankes/ rumah sakit. Tujuan pemeriksaan sebagian besar memeriksa TBC resisten obat. Hasil pemeriksaan TCM mendiagnosa $25,7 \%$ kasus TBC baru dan 5\% TBC resisten obat dari 1.528 pemeriksaan.
\end{abstract}

Kata Kunci: Rumah Sakit, Tes Cepat Molekuler, Xpert MTB/RIF, TBC

\begin{abstract}
Tuberculosis (TBC) is one of the health problems in the world, including in Indonesia. According to the World Health Organisation, the adult population is more exposed to TBC. An early TBC case finding is required to prevent disease transmission. The delay in diagnosis of TBC cases and treatment irregularities increase the chances of transmission in the community. The molecular rapid-test (MRT) examination can more accurately detect cases of confirmed TB culture than the microscopic one. Sorong District Hospital has conducted the molecular rapid-test to diagnose TBC since 2014. This study aims to describe the utilization of MRT in Sorong Regency from 2014-2018. This research used a cross-sectional design. The population were TBC suspects who were examined by MRT at the District Hospital. The samples were all TBC suspects referred to the Sorong District Hospital for MRT examinations from 2014 to July 2018. The secondary data collected from the patient identity, the origin of referral, the type of specimen examined, the purpose of examination, the patient treatment status, and MRT examination results. Most of the MRT examinations were male (54.5\%), aged 1554 years (71.3\%), the origin of referrals from internal health facilities (38.7\%) and the health centre (37.8\%). The MRT examination of most TBC patients with re-treatment cases was 88-90\% in 2014-2016 and 53-66\% in 2017-2018. Every year, drug-resistant TBC (RO) tests ranged (47-87\%). Total MRT examination results obtained $25.7 \%$ rifampin sensitive, and $5 \%$ rifampin resistant. Conclusion: Most of the MRT examinations were male, aged 15-54 years. The origin of the
\end{abstract}

Korespondensi:

Kristina

Puslitbang Upaya Kesehatan Masyarakat, Badan Litbang Kesehatan

E-mail: kristina80@ymail.com 
referral was from the internal health facility/hospital. The purpose of examination was mostly from the drug-resistant TB tests. The results of MRT examination diagnosed $25.7 \%$ of new TBC cases and $5 \%$ of drug-resistant TBC from the total of 1,528 examinations.

Keywords: Hospital, Molecular Rapid Test, Xpert MTB / RIF, TBC

\section{PENDAHULUAN}

Penyakit tuberkulosis (TBC) masih merupakan masalah kesehatan di dunia, termasuk di Indonesia. Menurut WHO 2009 lebih dari 80\% populasi orang dewasa sudah terpapar TBC, sehingga berpotensi sebagai sumber penularan. Hasil studi prevalensi TBC di Indonesia tahun 2013-2014 menemukan prevalensi TBC secara keseluruhan adalah 660 per 100.000 penduduk dan diperkirakan 1.600 .000 orang dengan TBC di Indonesia atau diestimasi sebesar 1.000.000 insiden TBC per tahun. Indonesia berkontribusi menyumbang kematian karena TBC sebesar $7 \%$ atau 100.000 kematian (WHO, 2017). Hasil studi Sampel Registration System 2016 di Indonesia melaporkan bahwa TBC paru merupakan penyebab kematian nomor lima setelah hipertensi dan berkontribusi 5,6\% dari seluruh kematian di Indonesia (Usman et al., 2018).

Strategi pengendalian TBC global bertujuan untuk menghentikan epidemik global TBC tahun 2035 yang ditandai dengan penurunan angka kematian akibat TBC sebesar 95\% dari angka tahun 2015 dan penurunan insiden TBC sebesar 90\% (menjadi 10/100.000 penduduk). Penemuan dan pengobatan kasus TBC sedini mungkin penting dalam upaya pencegahan penularan penyakit. Keterlambatan mendiagnosa kasus TBC dapat memperbesar peluang transmisi di masyarakat. Penegakan diagnosis penyakit TBC dapat dilakukan dengan anamnesis dan pemeriksaan fisik, selain itu juga dilakukan pemeriksaan sputum. Pemeriksaan sputum dapat dilakukan dengan: mikroskop biasa ataupun mikroskop fluoresens (pewarnaan khusus), biakan/kultur, dan menggunakan tes cepat molekuler GeneXpert MTB/RIF. Pada tahun 2010 WHO telah merekomendasikan pemeriksaan GeneXpert MTB/RIF untuk penegakan diagnosis TBC paru pada pasien dewasa, kemudian tahun 2013 merekomendasikan untuk diagnosis TBC anak dan ekstraparu (WHO, 2017). Kemudian tahun 2014, sebanyak 4,7 juta Catridge Xpert MTB / RIF dikirim ke beberapa negara (WHO, 2016).

Metode Tes cepat molekuler (Xpert MTB / RIF) merupakan perkembangan alat diagnostik yang dapat digunakan untuk mendeteksi adanya kuman mikrobakterium tuberculosis (MTB) secara otomatis dengan pemeriksaan molekuler dan juga dapat digunakan untuk mendeteksi resistensi MTB terhadap rifampisin. Tes tersebut merupakan pemeriksaan molekuler secara otomatis dan terintegrasi semua langkah Polymerase Chain Reaction (PCR) berdasarkan uji deoxyribonucleic acid (DNA) untuk mendeteksi bakteri tuberkolosis dan sekaligus mendeteksi resistensi bakteri terhadap rifampisin (Blanca I., 2014). Sensitivitas dan spesifitas TCM mendiagnosa TBC paru $88 \%$ dan $99 \%$, sedangkan sensitifitas dan spesifitas untuk mendeteksi rifampisin resisten adalah 95\% dan 98\%. Pemeriksaan TCM dengan menggunakan Xpert MTB/RIF dapat mendeteksi 90,3\% kasus konfirmasi kultur TBC dibanding dengan pemeriksaan mikroskopik $67,1 \%$ (Boehme et al., 2011). Hasil penelitian Hartini Ayu (2018) diperoleh bahwa metode GeneXpert lebih sensitive dibandingkan dengan metode mikroskopis (Hartina, Dewi and Wilson, 2018).

Pada tahun 2018 Puslitbang Upaya Kesehatan Masyarakat telah melakukan Studi Evaluasi Deteksi Kasus TBC dengan Tes Cepat Molekuler (TCM) di 42 kabupaten/kota termasuk kabupaten Sorong. RSUD Kabupaten Sorong adalah rumah sakit milik pemerintah Kabupaten Sorong Provinsi Papua Barat yang berstatus Badan Layanan Umum Daerah, dan merupakan rumah sakit rujukan daerah berstatus kelas C (Wafom, Tucunan and Rumayar, 2012). RSUD ini telah menerapkan tes cepat molekuler untuk mendiagnosa TBC cukup lama yaitu sejak 2014 hingga saat ini. Berdasarkan hal diatas maka penulis ingin mengetahui gambaran pemanfaatan TCM di RSUD Kabupaten Sorong dari Tahun 20142018. Tujuan umum penelitian adalah mengetahui gambaran pemanfaatan TCM di RSUD Kabupaten Sorong. Tujuan khusus: mengetahui gambaran karakteristik pasien dan asal rujukan pasien yang melakukan pemeriksaan TCM, serta mengetahui tujuan dan hasil pemeriksaan TCM per tahun.

\section{METODE}

Artikel ini merupakan analisis lanjut data Studi Evaluasi Deteksi Kasus TBC dengan Tes Cepat 
Molekuler (TCM) yang dilaksanakan di 42 kabupaten/ kota di Indonesia pada Tahun 2018. Pada artikel ini sampel hanya diambil satu kabupaten dari 42 kabupaten/kota studi. Lokasi penelitian yaitu RSUD Kabupaten Sorong. Pertimbangan pemilihan lokasi karena RSUD Kabupaten Sorong telah menggunakan TCM yaitu sejak 2014 sampai sekarang. Disain penelitian adalah potong lintang dengan populasi seluruh suspek TBC yang melakukan pemeriksaan TCM atau alat Xpert MTB/RIF untuk mendiagnosa TBC. Sampel adalah seluruh suspek TBC yang diperiksa TCM periode tahun 2014 sampai Juli 2018. Instrumen pengumpulan data dengan kuesioner.

Data sekunder yang dikumpulkan meliputi data individu suspek/terduga TBC yang diperiksa dengan TCM selama alat tersebut beroperasional dan hasilnya, baik yang berasal dari RSUD Kabupaten Sorong maupun di luar rumah sakit seperti Puskesmas, rumah sakit lainnya, klinik, dan dokter praktek mandiri (DPM) dari sejak tahun 2014 sampai Juli 2018. Variabel yang dikumpulkan antara lain: identitas pasien, asal rujukan, jenis pemeriksaan spesimen, spesimen yang diperiksa TCM, tujuan pemeriksaan, status pengobatan pasien, dan hasil pemeriksaan TCM. Pengelompokan umur berdasarkan kelompok umur $<15$ tahun, 15-54 tahun dan di 54 tahun keatas, dengan alasan untuk mengetahui penggunaan TCM pada kelompok usia anak, produktif dan usia tua. Asal rujukan adalah fasilitas kesehatan yang merujuk pasien atau suspek TBC untuk pemeriksaan TCM, dibedakan atas: internal rumah sakit (termasuk dari poli DOTS, poli penyakit dalam, poli anak), puskesmas, rumah sakit lain, praktek dokter/klinik.

Klasifikasi status atau riwayat pengobatan pasien berdasarkan pedoman TBC nasional 2014 yaitu: kasus baru dan kasus ulang. Pasien kasus baru adalah pasien yang belum pernah mendapat pengobatan TBC sebelumnya atau sudah pernah menelan OAT namun kurang dari satu bulan. Pasien kasus ulang adalah pasien yang pernah diobati TBC sebelumnya: termasuk pasien kambuh, pasien yg diobati kembali setelah gagal, dan pasien yang putus berobat (lost to follow up). Tujuan pemeriksaan TCM dibedakan atas: untuk pemeriksaan TBC paru, TBC resisten obat (RO), HIV-TBC dan DM-TBC. Hasil pemeriksaan TCM dikelompokkan atas hasil: negative, rifampisin sensitive, rifampisin resisten, rifampisin indeterminate, invalid dan error. Analisis data secara deskriptif, antara lain melihat gambaran asal rujukan pasien, status pengobatan, tujuan pemeriksaan dan hasil pemeriksaan TCM. Analisis data dilakukan dengan analisis univariat dan tabulasi silang menggunakan program SPSS 21

\section{HASIL}

Pada tabel 1 dapat dilihat karakteristik suspek TBC yang melakukan pemeriksaan TCM di rumah sakit. Jumlah sampel yang diperiksa dengan TCM sejak 2014-2018 sebanyak 1.528 orang, dan sebagian besar adalah laki-laki (54,5\%), umur $15-54$ tahun $(71,3 \%)$, dan asal rujukan dari internal rumah sakit $(38,7 \%)$ dan Puskesmas $(37,8 \%)$.

Pada gambar 1 dapat dilihat grafik suspek TBC yang melakukan pemeriksaan TCM berdasarkan status pengobatan. Tahun 2014 sampai 2016 yang melakukan pemeriksaan TCM adalah pasien dengan status pengobatan ulang sangat tinggi berkisar 8890\%, namun tahun 2017-2018 turun menjadi 53-66\%. Pada gambar 2 dapat dilihat tujuan pemeriksaan TCM sebagian besar untuk pemeriksaan TBC RO berkisar $47-88 \%$, kemudian TBC paru $(0,8-40 \%)$ dan yang paling sedikit pemeriksaan DM-TBC $(0,0-1,7 \%)$.

Pada tabel 2 dapat dilihat asal rujukan pasien yang melakukan pemeriksaan TCM. Asal rujukan sebagian besar dari internal rumah sakit $(38,7 \%)$ dan puskesmas $(37,8 \%)$ dan yang paling sedikit dari klinik/praktek dokter mandiri (6,0\%).

Pada tabel 3 dapat dilihat hasil pemeriksaan TCM sejak tahun 2014 sampai 2018. Hasil pemeriksaan TCM paling banyak ( $67,8 \%$ ) negatip. Selanjutnya

Tabel 1. Karakteristik Suspek TBC dan Asal rujukan yang Melakukan Pemeriksaan TCM di RSUD Kabupaten Sorong Tahun 2014-2018

\begin{tabular}{|c|c|c|c|}
\hline No & Karakteristik & $\begin{array}{l}\mathrm{N} \text { total } \\
(1.528)\end{array}$ & $\%$ \\
\hline \multicolumn{2}{|c|}{ Jenis Kelamin } & $\mathrm{n}$ & \\
\hline 1 & Laki-laki & 832 & 54,5 \\
\hline 2 & Perempuan & 696 & 45,5 \\
\hline \multicolumn{4}{|c|}{ Kelompok Umur } \\
\hline 3 & $<15$ tahun & 20 & 1,3 \\
\hline 4 & $15-54$ tahun & 1090 & 71,3 \\
\hline 5 & $>=55$ tahun & 418 & 27,4 \\
\hline \multicolumn{4}{|c|}{ Asal Rujukan Suspek TBC } \\
\hline 6 & Internal RS & 591 & 38,7 \\
\hline 7 & Puskesmas & 578 & 37,8 \\
\hline 8 & RS Lain & 266 & 17,4 \\
\hline 9 & Praktek Dokter/Klinik & 92 & 6,0 \\
\hline 10 & Tidak Diketahui & 1 & 0,1 \\
\hline
\end{tabular}




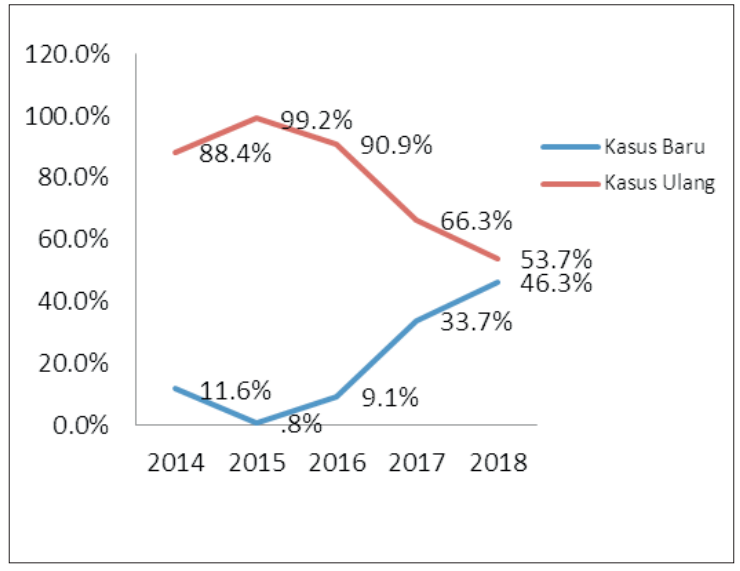

Gambar 1. Suspek TBC yang Melakukan Pemeriksaan TCM berdasarkan Status Pengobatan

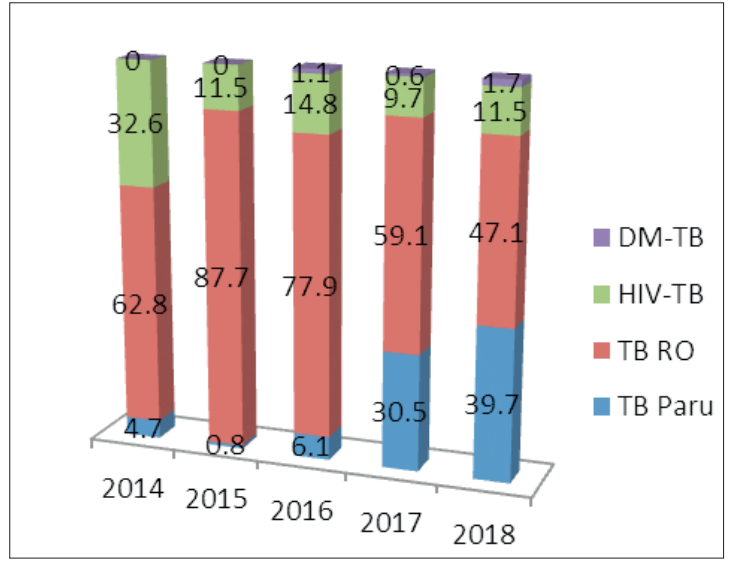

Gambar 2. Tujuan Pemeriksaan TCM di RSU Sorong

Tabel 2. Pemeriksaan TCM di RSUD Kabupaten Sorong berdasarkan Asal Rujukan Tahun 2014-2018

\begin{tabular}{|c|c|c|c|c|c|c|c|c|c|c|c|}
\hline \multirow{3}{*}{ Tahun } & \multicolumn{10}{|c|}{ Asal Rujukan } & \multirow{3}{*}{ Total } \\
\hline & \multicolumn{2}{|c|}{$\begin{array}{c}\text { Internal Rumah } \\
\text { Sakit }\end{array}$} & \multicolumn{2}{|c|}{ Puskesmas } & \multicolumn{2}{|c|}{$\begin{array}{c}\text { Rumah sakit } \\
\text { lainnya }\end{array}$} & \multicolumn{2}{|c|}{$\begin{array}{c}\text { Praktek dokter/ } \\
\text { klinik }\end{array}$} & \multicolumn{2}{|c|}{ Tidak Diketahui } & \\
\hline & $\mathbf{n}$ & $\%$ & $\mathbf{n}$ & $\%$ & $\mathbf{n}$ & $\%$ & $\mathbf{n}$ & $\%$ & $\mathbf{n}$ & $\%$ & \\
\hline 2014 & 22 & 51,2 & 8 & 18,6 & 9 & 20,9 & 4 & 9,3 & 0 & 0,0 & 43 \\
\hline 2015 & 54 & 44,3 & 38 & 31,1 & 26 & 21,3 & 4 & 3,3 & 0 & 0,0 & 122 \\
\hline 2016 & 96 & 36,9 & 97 & 36,9 & 52 & 19,8 & 18 & 6,8 & 0 & 0,0 & 263 \\
\hline 2017 & 234 & 37,2 & 261 & 41,5 & 104 & 16,5 & 29 & 4,6 & 1 & 0,2 & 629 \\
\hline 2018 & 185 & 39,3 & 174 & 36,9 & 75 & 15,9 & 37 & 7,9 & 0 & 0,0 & 471 \\
\hline Total & 591 & 38,7 & 578 & 37,8 & 266 & 17,4 & 92 & 6,0 & 1 & 0,0 & 1.528 \\
\hline
\end{tabular}

Tabel 3. Hasil Pemeriksaan TCM di RSUD Sorong Tahun 2014-2018

\begin{tabular}{|c|c|c|c|c|c|c|c|c|c|c|c|c|c|}
\hline \multirow{3}{*}{ Tahun } & \multicolumn{12}{|c|}{ Hasil Pemeriksaan TCM } & \multirow{3}{*}{$\begin{array}{c}\text { Total } \\
\mathbf{n}\end{array}$} \\
\hline & \multicolumn{2}{|c|}{ Negatif } & \multicolumn{2}{|c|}{$\begin{array}{l}\text { Rifampisin } \\
\text { Sensitif }\end{array}$} & \multicolumn{2}{|c|}{$\begin{array}{l}\text { Rifampisin } \\
\text { Resisten }\end{array}$} & \multicolumn{2}{|c|}{$\begin{array}{l}\text { Rifampisin } \\
\text { Indeterminate }\end{array}$} & \multicolumn{2}{|c|}{ Invalid } & \multicolumn{2}{|c|}{ Error } & \\
\hline & $\mathbf{n}$ & $\%$ & $\mathbf{n}$ & $\%$ & $\mathbf{n}$ & $\%$ & $\mathbf{n}$ & $\%$ & $\mathbf{n}$ & $\%$ & $\mathbf{n}$ & $\%$ & \\
\hline 2014 & 30 & 69,8 & 7 & 16,3 & 4 & 9,3 & 0 & 0,0 & 1 & 2,3 & 1 & 2,3 & 43 \\
\hline 2015 & 69 & 56,6 & 38 & 31,1 & 11 & 9,0 & 0 & 0,0 & 4 & 3,3 & 0 & 0,0 & 122 \\
\hline 2016 & 173 & 65,8 & 67 & 25,5 & 18 & 6,8 & 0 & 0,0 & 3 & 1,1 & 2 & 0,8 & 263 \\
\hline 2017 & 449 & 71,4 & 148 & 23,5 & 25 & 4,0 & 6 & 1,0 & 1 & 0,2 & 0 & 0,0 & 629 \\
\hline 2018 & 315 & 66,9 & 132 & 28,0 & 18 & 3,8 & 5 & 1,1 & 1 & 0,2 & 0 & 0,0 & 471 \\
\hline Total & 1036 & 67,8 & 392 & 25,7 & 76 & 5,0 & 11 & 0,7 & 10 & 0,7 & 3 & 0,2 & 1528 \\
\hline
\end{tabular}

ditemui kasus TBC sebanyak $25,7 \%$ rifampisin sensitive, dan $5 \%$ rifampisin resisten. Masih terdapat $0,19 \%$ dari 1.528 hasilnya rifampisin indeterminate, invalid dan error.

\section{PEMBAHASAN}

RSUD Kabupaten Sorong adalah rumah sakit milik pemerintah Kabupaten Sorong Provinsi Papua
Barat dengan status Badan Layanan Umum Daerah, dan merupakan rumah sakit rujukan daerah. Sejak tahun 2009 rumah sakit telah menerapkan program DOTS dalam pelayanan pasien TBC. Kemudian sejak 2014 hingga sekarang telah menerapkan metode TCM dalam mendiagnosa TBC.

Hasil penelitian diperoleh total jumlah suspek TBC yang diperiksa TCM selama periode Januari 2014-Juli 2018 adalah 1.528. Sebagian besar 
suspek TBC yang diperiksa adalah laki-laki (54\%), dan berusia produktif rata-rata berumur 15-54 tahun (71\%). Hal ini sama dengan hasil penelitian yang dilakukan di 42 rumah sakit di Indonesia, dimana pemeriksaan diagnose TBC dengan TCM juga paling banyak laki laki dan pada kelompok umur 15-54 (Tobing and Lolong, 2019). Hasil penelitian Paulus Mario Christopher dan Bajrami R diperoleh laki-laki lebih banyak periksa TCM dibandingkan perempuan (Christopher, Cucunawangsih and Widysanto, 2017), begitu juga dengan penelitian di RSU Tangerang Selatan dimana laki-laki yang diperiksa TCM paling banyak (63\%) dibanding perempuan (35\%).

Pemanfaatan penggunaan TCM atau alat tes cepat GeneXpert MTB/RIF saat ini bukan hanya ditujukan untuk diagnosis terduga TBC resisten obat dan TBC HIV, selanjutnya akan dikembangkan untuk diagnosis TBC baru pada anak, TBC Diabetes Melitus, TBC ekstra paru, serta diagnosis pada terduga TBC hasil BTA negatif.

Hasil penelitian diketahui bahwa pemeriksaan TCM di rumah sakit Kabupaten Sorong sebagian besar bertujuan untuk pemeriksaan TBC RO yaitu berkisar (47-88\%), dan sisanya untuk pemeriksaan TBC paru, HIV-TBC dan DM-TBC (gambar 2). Hal ini juga selaras dengan banyaknya rata-rata jumlah kasus ulang yang diperiksa setiap tahun berkisar 54$99 \%$ (gambar 1). Kasus ulang dalam hal ini adalah pasien yang pernah diobati TBC sebelumnya, termasuk pasien kambuh, pasien yang diobati kembali setelah gagal, pasien yang diobati kembali setelah putus berobat dan pasien TBC yang pernah diobati namun hasil akhir pengobatan sebelumnya tidak diketahui. Tahun 2014-2016 rata-rata sebanyak 89\% pasien kasus lama memanfaatkan pemeriksaan TCM sedangkan kasus baru hanya berkisar 0,8-11,6\%. Hal ini berbanding terbalik dengan hasil penelitian di 42 Kabupaten kota, dimana secara keseluruhan TCM paling banyak dimanfaatkan oleh pasien kasus baru dibandingkan kasus lama. (Badan Penelitian dan Pengembangan Kesehatan RI, 2018).

Pemanfaatan TCM untuk pemeriksaan HIVTBCdi RSUD Kabupaten Sorong sudah dilakukan sejak 2014. Persentase pemeriksaan HIV-TBC dengan TCM paling tinggi tahun 2014 yaitu 32,6\% dari 43 (14 orang) yang diperiksa. Selanjutnya pada tahun 2016-2018 persentase pemeriksaan HIV TBC dengan TCM menurun tapi dari segi jumlah meningkat yaitu berkisar 39-54 orang (9,7\%-14,8\%). $\mathrm{Hal}$ ini dapat menjadi perhatian pihak rumah sakit maupun Dinas Kesehatan Kabupaten Sorong untuk melakukan peningkatan program pengendalian penyakit HIVIAIDS, karena penyakit HIV sangat berkaitan dengan TBC. Biasanya orang yang terkena HIVIAIDS daya tahan tubuhnya akan menurun sehingga mudah terserang penyakit lain seperti TBC. Di seluruh Asia Pasifik sebanyak 40-70\% pasien AIDS/HIV menderita TBC dan penyakit TBC merupakan pembunuh terbesar pasien AIDS/HIV (Narain, Jai P., 2004). Di Indonesia diperkirakan $50 \%$ koinfeksi dari HIVIAIDS adalah TBC (Lolong and Pangaribuan, 2010). Hasil penelitian di RSUD Wangaya Bali diperoleh selama setahun (Juli 2017Juli 2018) jumlah presentasi pemeriksaan HIV-TBC dengan TCM sebesar 13,7\% dari 633 suspek yang pemeriksaan (Novianti., Simarmata and Lolong, 2020). Faktor risiko yang memiliki hubungan dengan koinfeksi HIV-TBC adalah kadar CD4 dan kadar HB. (Sylvani, Handajani and Gani, 2019) Hasil penelitian Ni'mal Muna 2019 diketahui bahwa dari 30 pasien HIV yang memiliki infeksi oportunistik TBC sebanyak 16 pasien HIV yang langsung menjalani pengobatan TBC (Muna and Cahyati, 2019).

Tahun 2014-2015 RSUD Kab Sorong belum melakukan pemeriksaan DM TBC dengan TCM. Setelah tahun 2016-2018 suspek yang melakukan pemeriksaan DM-TBC bervariasi jumlahnya yaitu 3-8 orang dalam setahun. Menurut International Diabetes Federation (2012) penderita diabetes melitus (DM) berisiko tinggi atau 2,5 kali menderita TBC dibanding yang tidak DM. Hasil penelitian Dyah Retno Wulandari, 2013 disebutkan diabetes mellitus meningkatkan risiko infeksi TBC aktif sebesar 3,11 kali. DM dapat menjadi penyebab perburukan gejala dan meningkatkan keparahan infeksi TBC.(Wulandari and Sugiri, 2013). Pasien yang menderita DM-TBC lebih sering mempunyai manifestasi klinis yang lebih berat dibanding tanpa DM dan penderita DM berisiko TBC 1,5-8,9 kali terkena TBC dibanding tanpa DM. Prevalensi DM pada TBC berkisar 5,4-44,0\%(Mihardja, Lolong and Ghani, 2016). DM merupakan komorbid TBC yang berat karena berdampak pada meningkatnya risiko kejadian TBC RO (Rosdiana, 2017).

Pemeriksaan TCM yang dirujuk dari pasien internal rumah sakit sendiri berkisar (44-51\%) tahun 2014-2015, namun setelah 2016 -2018 turun menjadi (37-39\%). Sebaliknya yang dari Puskesmas meningkat dari 18-31\% tahun 2014-2015 menjadi (37$41 \%$ ) tahun 2016-2018. Hal ini menunjukkan bahwa Puskesmas sudah mulai menerapkan Permenkes 67 tahun 2016 yang mengatakan bahwa untuk 
mendiagnosa TBC dapat menggunakan TCM karena tingkat keakuratannya lebih tinggi dibandingkan dengan mikroskopis. Sensitivitas dan spesifitas TCM mendiagnosa TBC paru $88 \%$ dan 99\%, sedangkan sensitifitas dan spesifitas untuk mendeteksi rifampisin resisten adalah $95 \%$ dan $98 \%$.

Pasien rujukan dari rumah sakit lainnya sebesar rata-rata $21 \%$ tahun $2014-2015$ turun menjadi $17 \%$ tahun 2016-2018. Rujukan yang berasal dari klinik atau DPM sangat kecil di tahun 2014-2015 hanya 4 orang namun di tahun berikutnya meningkat menjadi 18-37 orang. RSUD Kabupaten Sorong merupakan rumah sakit satu-satunya yang menerima rujukan pemeriksaan TCM. Pasien yang dirujuk bukan hanya berasal dari fasyankes di wilayah kabupaten Sorong tapi juga dari kabupaten tetangga seperti Kabupaten Manokwari, Sorong Selatan, Kota Sorong dll. Pemanfaatan TCM di RSUD Kab Sorong oleh fasilitas layanan kesehatan lainnya menunjukkan bahwa RSUD Kab Sorong telah menjalankan program penanggulangan TBC nasional. Menurut buku Petunjuk Teknis TCM, pemeriksaan TCM dapat digunakan untuk pasien yang berasal dari sektor pemerintah dan swasta sesuai dengan jejaring yang diatur dalam Program Nasional Penanggulangan TBC. Hasil penelitian lain diperoleh bahwa pasien yang diperiksa TCM paling banyak dirujuk dari internal rumah sakit $(71,5 \%)$, kemudian dari Puskesmas $(18,7 \%)$ dan sisanya dari rumah sakit swasta, klinik, dan DPM (Tobing and Lolong, 2019).

Pada kondisi dimana pemeriksaan TCM tidak memungkinkan (misalnya alat TCM melampaui kapasitas pemeriksaan, alat TCM mengalami kerusakan, dII), maka penegakan diagnosis TBC dilakukan dengan pemeriksaan mikroskopis. Fasilitas kesehatan yang tidak menggunakan metode TCM dan kesulitan mengakses TCM, penegakan diagnosis TBC tetap menggunakan mikroskop. Jika terduga TBC adalah kelompok terduga TBC RO dan terduga TBC dengan HIV positif, harus tetap diupayakan untuk dilakukan penegakan diagnosis TBC dengan TCM, dengan cara melakukan rujukan ke layanan TCM terdekat, baik dengan cara rujukan pasien atau rujukan specimen.

Hasil penelitian menemukan dari 1.528 pemeriksaan TCM selama periode 2014-2018 ditemukan hasil negatif $(67,8 \%)$, rifampisin sensitive $(25,7 \%)$, resisten $(5 \%)$, dan sisanya $(1,5 \%)$ terdiri dari rifampisin indeterminate, invalid dan error. Hasil penelitian lain diperoleh dari 40 sampel dengan metode RT-PCR GeneXpert diperoleh 40\% (16 orang) positif dan $60 \%$ (24 orang) negative TBC serta tidak didapatkan adanya resistensi rifampisin (Kurniawan et al., 2016). Pada pemeriksaan TCM yang hasilnya invalid, kondisi seperti ini dapat terjadi karena sampel tidak dapat diproses dengan benar atau terdapat gangguan pada proses PCR, sedangkan untuk yang hasil pemeriksaan error hal ini terjadi kegagalan komponen sistem pada saat proses PCR sehingga MTB tidak dapat terdeteksi dan tidak bisa ditentukan. Menurut penelitian lain bila hasil pemeriksaan rifampisin indeterminate, invalid dan eror dilakukan pemeriksaan ulang (Bodmer and Ströhle, 2012). Pada beberapa daerah masih ada fasyankes tidak mengulang hasil TCM yang indeterminated, error, invalid dan tidak ada result. Hal ini kemungkinan karena sputum suspek terbatas, si pasien tidak datang lagi membawa sputum, dan keterbatasan catriage. Hasil studi Studi Evaluasi Deteksi Kasus TBC Dengan Tes Cepat Molekuler (TCM) Di Indonesia Tahun 2018, ditemui ada sekitar 60 kasus yang harus diulang TCM tapi tidak dilakukan (Badan Penelitian dan Pengembangan Kesehatan RI, 2018). Hasil penelitian di RSUD kota Tangerang tahun 2017 diperoleh jumlah positif TBC (rifampisin sensitif) sebesar $112(29,9 \%)$ sedangkan rifampisin resisten $42(11.2 \%)$ sisanya $(53,3 \%)$ negatif dan indeterminate $0,8 \%$, invalid $1,6 \%$, error $2,4 \%$ dan no result 0,8\%. Menurut buku petunjuk teknis TCM 2016 apabila hasil TCM indeterminated, error, invalid dan tidak ada result maka harus dilakukan pemeriksaan ulang TCM.

\section{KESIMPULAN DAN SARAN}

\section{Kesimpulan}

TCM di RSUD Kabupaten Sorong sebagian besar memeriksa laki-laki, umur 15-54 tahun dan asal rujukan dari internal fasyankes/rumah sakit. Rujukan yg diperiksa TCM sebagian besar berasal dari internal rumah sakit, kemudian dari puskesmas, rumas sakit lainnya, klinik/DPM baik yang berasal dari kabupaten Sorong maupun luar kabupaten Sorong. Tujuan pemeriksaan TCM sebagian besar untuk pemeriksaan TBC resisten obat. Hasil pemeriksaan TCM selama 2014-2018 mampu mendiagnosa 25,7\% kasus TBC baru dan 5\% TBC resisten dari 1528 pemeriksaan suspek.

\section{Saran}

Metode TCM dengan sensitifitas dan spesivisitas yang tinggi serta kecepatan diagnosa TBC diusulkan 
untuk digunakan terutama di daerah yang kasus TBCnya tinggi.

Petugas kesehatan perlu meningkatkan sosialisasi pemanfaatan TCM ke masyarakat agar rujukan pemeriksaan TCM dari fasilitas kesehatan lain terutama dari rumah sakit lainnya dan klinik/DPM meningkat.

\section{UCAPAN TERIMA KASIH}

Terima kasih kami ucapkan kepada kepala Puslitbang Upaya Kesehatan Masyarakat yang telah memberikan kesempatan untuk melakukan penelitian Studi Evaluasi Deteksi Kasus TBC dengan Tes Cepat Molekuler (TCM) yang dilaksanakan di 42 kabupaten/ kota di Indonesia pada Tahun 2018sehingga data nya dapat dianalisis lebih lanjut untuk membuat artikel ini. Terima kasih juga kepada para reviewer dan dewan redaksi yang sudah memberikan masukan dalam penulisan artikel ini.

\section{KONTRIBUTOR PENULIS}

Penulis pertama, kedua dan ketiga sebagai contributor utama. Tugas ketiga contributor utama bersama-sama membuat isi artikel dari mulai abstrak, pendahuluan, metode, analisa data, hasil, pembahasan, kesimpulan, dan membuat daftar pustaka.

\section{DAFTAR PUSTAKA}

Blanca I., R. (2014) ‘Diabetes and Tuberculosis', Microbiology Spectrum, 2(3), pp. 1-16. doi: https://doi.org/10.1128/ microbiolspec.

Bodmer, T. and Ströhle, A. (2012) 'Diagnosing pulmonary tuberculosis with the Xpert MTB/RIF test', Journal of Visualized Experiments, (62), pp. 1-6. doi: https:// doi.org/10.3791/3547.

Boehme, C. C. et al. (2011) 'Feasibility, diagnostic accuracy, and effectiveness of decentralised use of the Xpert MTB/RIF test for diagnosis of tuberculosis and multidrug resistance: A multicentre implementation study', The Lancet. Elsevier Ltd, 377(9776), pp. 1495-1505. doi: https://doi.org/10.1016/S01406736(11)60438-8.

Christopher, P. M., Cucunawangsih and Widysanto, A. (2017) 'Treatment Outcomes and Associated Factors in Tuberculosis Patients at Jimma University Medical Center: A 5-Year Retrospective Study Gemeda', International Journal of Mycobacteriology, 6(3), pp. 239-245. doi: https://doi.org/10.4103/ijmy.ijmy.
Hartina, A., Dewi, S. S. and Wilson, W. (2018) Analisis Perbedaan Hasil Pemeriksaan Suspek TBC Paru Dengan Genexpert Dan Mikroskopis.

Kementerian Kesehatan RI. (2016) Peraturan Menteri Kesehatan Republik Indonesia no 67 tahun 2016 tentang Penanggulangan Tuberkulosis.

Kurniawan, E. et al. (2016) 'Nilai Diagnostik Metode "Real Time" PCR GeneXpert pada TBC Paru BTA Negatif', Jurnal Kesehatan Andalas, 5(3), pp. 730-738. doi: https://doi.org/10.25077/jka.v5i3.609.

Lolong, D. B. and Pangaribuan, L. (2010) 'Tuberkulosis Dan HIVIAIDS Penyebab Utama Kematian di Kota dan Kabupaten Jayapura, 2007', Jurnal Ekologi Kesehatan, 9(2), pp. 1184-1191.

Mihardja, L., Lolong, D. B. and Ghani, L. (2016) 'Prevalensi Diabetes Melitus Pada Tuberkulosis Dan Masalah Terapi', Jurnal Ekologi Kesehatan, 14(4), pp. 350-358. doi: 1 https://doi.org/10.22435/jek.v14i4.4714.350358.

Muna, N. and Cahyati, W. H. (2019) 'Determinan Kejadian Tuberkulosis pada Orang dengan HIVIAIDS', Higeia Journal of Public Health Research and Development, 2(3), pp. 168-178. doi: https://doi.org/10.15294.

Narain, Jai P., Y.-R. Lo (2004) 'Epidemiology of HIV-TBC in asia', Indian Journal of Medical Research, 120(4), pp. 277-289.

Novianti., Simarmata, O. S. and Lolong, D. B. (2020) 'Pemanfaatan Tes Cepat Molekuler (TCM) GeneXpert sebagai Alat Diagnostik TBC Paru di RSUD Wangaya Kota Denpasar', Journal Ekologi Kesehatan, 18(3), pp. 135-148.

Rosdiana, D. (2017) 'Tuberkulosis Paru Resisten Obat dengan Komorbiditas Diabetes Mellitus', Jurnal Kesehatan Melayu, 1(1), p. 45. doi: https://doi. org/10.26891/jkm.v1i1.2017.45-50.

Sylvani, M. A., Handajani, Y. S. and Gani, L. (2019) ‘Faktor Risiko Komorbid HIV dan Tuberkulosis di Rumah Sakit Umum Daerah Merauke', pp. 211-217.

Tobing, K. and Lolong, D. B. (2019) 'Gambaran diagnosa TBC dengan metode tes cepat molekuler di rumah sakit', Prosiding Seminar Nasional XXVIII "Kimia dalam Industri dan Lingkungan”, pp. 81-86.

Usman, Y. et al. (2018) 'Indonesia's sample registration system in 2018: A work in progress', Journal of Population and Social Studies, 27(1), pp. 39-52. doi: https://doi.org/10.25133/JPSSV27N1.003.

Wafom, Y., Tucunan, A. A. and Rumayar, A. A. (2012) Kualitas Jasa Pelayanan Dan Kepuasan Pasien Rawat Inap Di RSUD Kabupaten Sorong.

WHO (2016) 'WHO treatment guidelines for drug- resistant tuberculosis 2016', World health organisation, (October).

WHO (2017) Global Tuberculosis Report 2017. doi: https:// doi.org/10.1001/jama.2014.11450.

Wulandari, D. R. and Sugiri, Y. J. (2013) 'Diabetes Melitus dan Permasalahannya pada Infeksi Tuberkulosis', 33(2), pp. 126-134. 